\title{
Diversity, community structure and conservation status of an Atlantic Forest fragment in Rio de Janeiro State, Brazil
}

\author{
Vinicius Costa Cysneiros ${ }^{1,2}$, Joaquim de Oliveira Mendonça-Junior ${ }^{1}$, Tatiana Dias Gaui ${ }^{1}$ \& Denise Monte Braz ${ }^{I}$ \\ ${ }^{1}$ Universidade Federal Rural do Rio de Janeiro, Instituto de Biologia, Departamento de Botânica, \\ Seropédica, RJ, Brazil. \\ ${ }^{2}$ Corresponding author: Vinicius Costa Cysneiros, e-mail: vccysneiros.florestal@gmail.com
}

CYSNEIROS, V.C., MENDONÇA-JUNIOR, J.O., GAUI, T.D., BRAZ, D.M. Diversity, community structure and conservation status of an Atlantic Forest fragment in Rio de Janeiro State, Brazil. Biota Neotropica. 15(2): e20140132. http://dx.doi.org/10.1590/1676-06032015013214

\begin{abstract}
The State of Rio de Janeiro still holds unknown portions of the Atlantic Forest, which represent gaps in the knowledge of this ecosystem. Paracambi and neighbor municipal districts comprise a vast stretch of virtually unknown forest that makes up part of the Serra do Mar biodiversity corridor. The following study describes the tree community structure in a stretch of the ombrophilous Atlantic Forest, in the Parque Natural Municipal do Curió (Curio MNP), Paracambi, Rio de Janeiro, which serves as the basis to evaluate species diversity and conservation status. The altitudes in the area ranges from 100 to $690 \mathrm{~m}$ and the climate varies from mild subtropical to tropical hot and humid. Forty plots $(10 \times 10 \mathrm{~m})$ were randomly placed along the area, where all the stems equal to or greater than five centimeters $(5 \mathrm{~cm})$ diameter at breast high from ground level were measured. A total of 749 individuals, pertaining to 128 genera and 210 species were recorded, eight of which are listed as threatened of extinction in the Brazilian flora. The Shannon-Weaver diversity index $\left(\mathrm{H}^{\prime}\right)$ was 4.7 nat.ind. ${ }^{-1}$ and the species with greater importance value was Pseudopiptadenia contorta $\left(1.6460 \mathrm{~m}^{2} ; 18\right.$ individuals) while the most common species were Senefeldera vertcilata (48) and Actinostemon verticilatus (47 individuals). Despite the sample area being a little smaller than that commonly adopted in tropical studies, data pointed to a richness hitherto not registered in any other study for the State of Rio de Janeiro, no matter the inclusion criteria used, and also confirmed by the two estimator indices used, which have revealed very similar results. The vertical forest structure, the values associated to the successional stage of the species and other aspects of community structure indicate that the Curio MNP encompasses forest stretches in advanced stages of ecological succession. Besides its key location for the connectivity of forest fragments in the region, the results emphasize the ecological importance of this forest remnant and the need for its conservation.

Keywords: tropical rain forest, phytosociology, ecological succession, Serra do Mar biodiversity corridor, Curio Municipal Natural Park- Paracambi.
\end{abstract}

CYSNEIROS, V.C., MENDONÇA-JUNIOR, J.O., GAUI, T.D., BRAZ, D.M. Diversidade, estrutura e estado de conservação de um fragmento da Floresta Atlântica no Estado do Rio de Janeiro. Biota Neotropica. 15(2): e20140132. http://dx.doi.org/10.1590/1676-06032015013214

Resumo: O estado do Rio de Janeiro ainda detém porções desconhecidas da Floresta Atlântica, apontadas como lacunas no conhecimento desse ecossistema. Paracambi e municípios vizinhos contêm um extenso trecho florestado praticamente desconhecido que compõe o corredor ecológico da Serra do Mar. Este estudo descreve a estrutura do componente arbóreo da Floresta Atlântica ombrófila em uma porção desse contínuo florestal, no Parque Natural Municipal do Curió (PNM Curió), Paracambi, Rio de Janeiro, que serviu de base para avaliar a riqueza específica e seu estado de conservação. A altitude atinge de 100 a 690 m.s.n.m na área estudada e o clima varia de subtropical brando a tropical quente e úmido. Foram alocadas 40 parcelas de $10 \times 10 \mathrm{~m}\left(100 \mathrm{~m}^{2}\right)$ distribuídas arbitrariamente ao longo do Parque, onde todos os indivíduos com diâmetro à altura do peito maior ou igual a cinco centímetros $(\geq 5 \mathrm{~cm})$ foram mensurados. Foram amostrados 749 indivíduos, somando 128 gêneros e 210 espécies, oito das quais listadas como ameaçadas de extinção na flora brasileira. O índice de diversidade de ShannonWeaver $\left(\mathrm{H}^{\prime}\right)$ foi 4.7 nat.ind. ${ }^{-1}$ e a espécie com maior valor de importância foi Pseudopiptadenia contorta (1.6460 $\mathrm{m}^{2} ; 18$ indivíduos) enquanto que as espécies mais comuns foram Senefeldera vertcilata (48) e Actinostemon verticilatus (47). Apesar da área de estudo menor que a comumente adotada em estudos semelhantes, os dados apontaram para uma riqueza até então não registrada em nenhum outro estudo para o estado do Rio de Janeiro, independente do critério de inclusão adotado, o que também foi confirmado pelos dois estimadores de riqueza utilizados, que apresentaram resultados muito semelhantes. 
Cysneiros, V.C. et al.

\begin{abstract}
A estrutura vertical da floresta, a associação dos valores obtidos ao estágio sucessional das espécies e outros aspectos da estrutura da comunidade, indicam que o PNM Curió engloba trechos de floresta em estágio avançado de sucessão ecológica. Além da localização chave na conectividade de fragmentos florestais na região, os resultados enfatizam a importância ecológica desse remanescente e da necessidade de sua conservação.

Keywords: floresta ombrófila, fitossociologia, sucessão ecológica, corredor ecológico da Serra do Mar, Parque Natural Municipal do Curió- Paracambi.
\end{abstract}

\section{Introduction}

Due to its high levels of endemism and biodiversity, the Atlantic Forest is considered a biome of unique biological complexity (Peixoto 1991, Stehmann et al. 2009). This feature, combined with its history of degradation, makes it one of the most threatened ecosystems in the world (Myers et al. 2000). Extensive areas have been devastated without any knowledge and many species have become extinct before they were even described by science (Guedes-Bruni et al. 2002, Borém \& Oliveira-Filho 2002). Currently, the Atlantic Forest is reduced to fragments, mostly concentrated in the Brazilian Southeast and South, in areas of rugged topography inappropriate for agricultural activities and within conservation units (Martins 1991, Leitão-Filho et al. 1993, Kurtz \& Araújo 2000, Ribeiro et al. 2009). Although fragmented, high rates of endemism found in this large forest block, with its different formations (Oliveira-Filho \& Fontes 2000, Stehmann et al. 2009), make the remaining forest fragments singular relics.

Floristic studies are essential to the understanding and conservation of tropical forests (Silva \& Leitão-Filho 1982, Guedes-Bruni et al. 1997). Along with this, structural surveys, which include quantitative traits, are among the best tools for characterization of the vegetation and the identification of the ecosystem successional status (Guedes-Bruni et al. 1997). Floristic and structural surveys make it possible to identify the potential for sustainable use of forest resources, as well as develop strategies to preserve and recover degraded areas and to quantify the richness, abundance and diversity of plant communities (Fonseca \& Sá 1997, Scarano 1998).

The State of Rio de Janeiro still encompasses preserved portions of the Atlantic Forest, especially in the state interior and in mountain regions. Strategies for biodiversity conservation in the state (Bergalho 2009) call attention to the lack of knowledge especially in much of the Middle Paraíba River region, in the South of the state, and virtually the entire Northwest Region. These regions are still home to remaining forest fragments and efforts to fill these gaps are essential for understanding the flora of Rio de Janeiro and the Atlantic Forest as a whole. In the poorly known southern portion of the state, the Parque Natural Municipal do Curió (Municipal Natural Park of Curió) (Curio MNP) makes up part of the biodiversity corridor of the Serra do Mar, between the mountain ranges of Tinguá and Bocaina. Investigations of the flora, microorganisms and soil (Fraga et al. 2012) have indicated high rates of diversity in the area and its good conservation condition.

The importance of connectivity between forest fragments in the region makes the Curio MNP a strategic area for the maintenance of plant diversity in the state, which can serve as germoplasm stock and as a reference for measuring floristic restoration, especially in nearby areas. For these reasons, the present study aimed to elucidate the structure and floristic composition of the tree component within a forest fragment of the Curio MNP, including comparison of its richness to other forested areas in the State of Rio de Janeiro, and characterization of its horizontal and vertical structures to evaluate the conservation status of this vegetation.

\section{Material and Methods}

Study area - The area is located in the municipality of Paracambi, Rio de Janeiro, between the geographical coordinates $22^{\circ} 36^{\prime} 39^{\prime \prime} \mathrm{S}$ to $43^{\circ} 42^{\prime} 33^{\prime \prime} \mathrm{W}$ (Figure 1), covering an area of approximately 900 ha (Fraga et al. 2012). Paracambi is located at the southern limit of the metropolitan region of the state, and the area of the Curio MNP lies at the limits of the municipality, bordering the Middle Paraíba River and SouthCentral regions of the state (Bergalho 2009). The topography in Curio MNP is distinctly hilly, with altitudes ranging from 100 to 690 m.a.s.l.; the climate ranges from mild subtropical in most mountain areas with a dry winter and hot and rainy summer, and tropical hot and humid in other areas, classified as $\mathrm{Aw}$ according to Köppen-Geiger; the average annual temperature is $23.4^{\circ} \mathrm{C}$ (Fraga et al. 2012). Rich in water resources, the park is part of the Guandu River basin and sub-basin of the Macacos and Cascata streams, with springs that run along almost its entire length. The fragment is mostly woody and covered by the lowland and submontane Atlantic rain forest (IBGE 2012, Oliveita-Filho \& Fontes, 2000). The area of the Curio MNP is inserted in the Southern Atlantic Forest Corridor, or the Serra do Mar Corridor, linking the forests of Rio de Janeiro and São Paulo States (Tabarelli et al. 2005).

Sampling and analysis - Data were collected between February 2009 and March 2010 by means of simple random sampling (Scolforo \& Mello 2006) using the plot method (Mueller-Dombois \& Ellenberg 1974). Aiming to include the largest possible area of the local vegetation, the sample was distributed over the entire area of the park, between 150-524 m.a.s.l. altitude, excluding the areas of access and of edge effect. Forty sampling units with dimensions of $10 \times 10 \mathrm{~m}\left(100 \mathrm{~m}^{2}\right)$ were allocated, in which all individuals with diameter of at least five $\mathrm{cm}$ at breast height (DBH, $1.30 \mathrm{~m}$ above the ground) were measured using a measure tape and a $2 \mathrm{~m}$ rod to estimate total height. Fertile and sterile botanical material was collected and treated under usual herbarium techniques (Guedes-Bruni et al. 2002) for posterior inclusion in the collection of the Herbarium RBR of the Department of Botany/IB, Universidade Federal Rural do Rio de Janeiro (UFRRJ). The identification was based on consultation of the collections of RBR and RB (Instituto de Pesquisa Jardim Botânico do Rio de Janeiro) Herbaria, specialized bibliographies and, when possible, by consulting taxonomic specialists. The sources used for current taxonomic nomenclature were the Lista das Espécies da Flora do Brasil (2014), Tropicos (2013) and the International Index of Plant Names (IPNI, 2013) databases. The classification system 


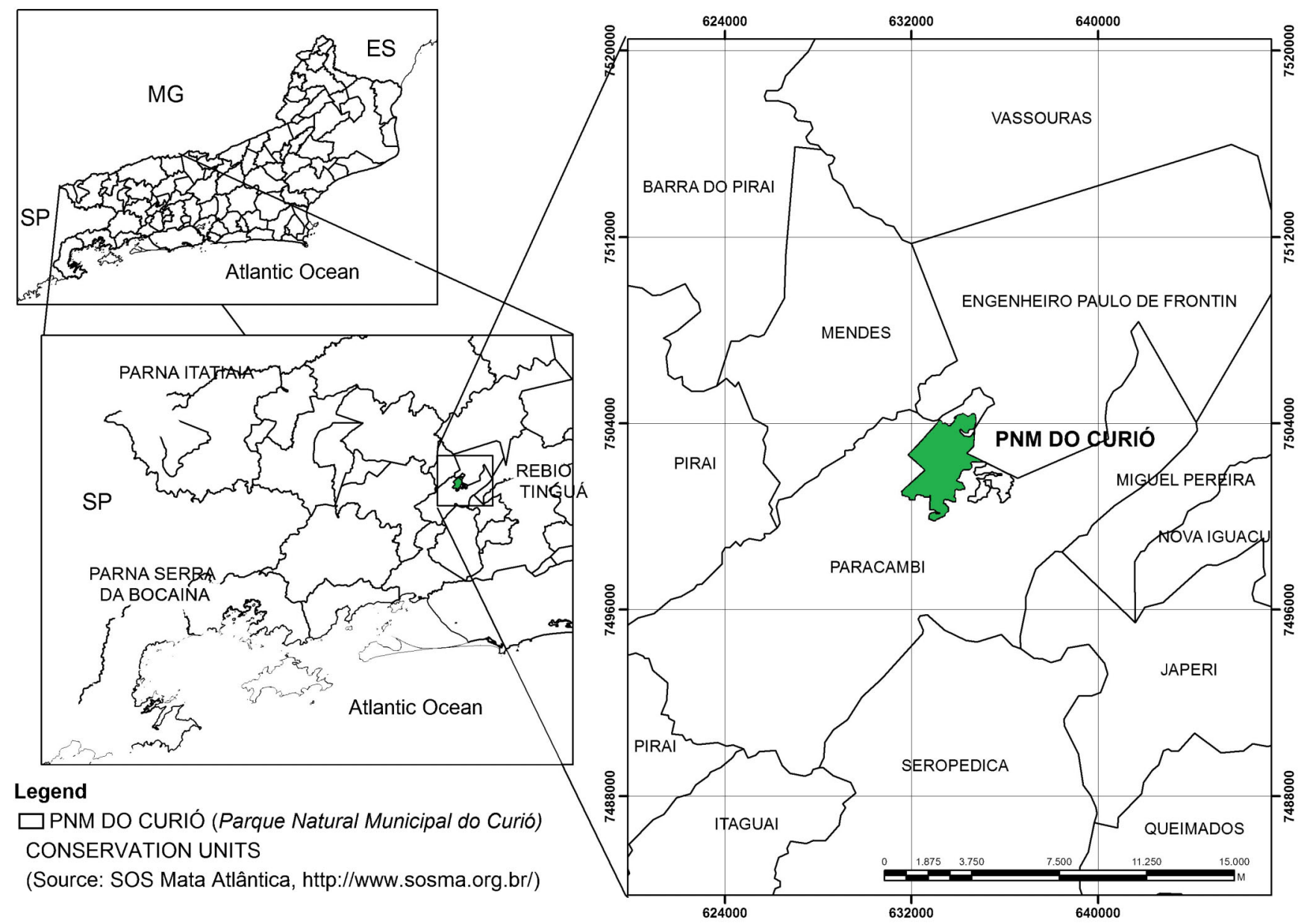

Figure 1. Geographic location of the Parque Natural Municipal do Curió (Municipal Natural Park of Curió) (Curio MNP), Municipal District of Paracambi, State of Rio de Janeiro, Brazil.

adopted followed the APG III (APG, 2009). Unidentified species were named (sp.) and numbered as "morpho-species", which allowed for their inclusion in the estimation of phytosociological and diversity indexes.

For all analysis, only living, individual trees were considered. The species accumulation curve was constructed using the software EstimateS 8:20, with the support of Microsoft Excel $^{\circledR}$ spreadsheets. This curve minimizes the problems caused by the collector curve, because it is an average curve, generated from several distinct and random orderings (Magurran 2011, Schilling \& Batista 2008). For its construction, 1000 simulations were performed with the goal of changing the sample unit entry order and assess the degree of stability of the sample (Pillar 2004 Apud Schilling \& Batista 2008) on the basis of the central limit theorem (Ferreira 2009). From the average accumulation of number of species as a function of the area sampled, species richness was estimated through the estimators Chao 1 and Jackknife 1 (Magurran 2011). The floristic diversity of the area and the distribution of the individuals per species were estimated through the Shannon-Weaver $\left(\mathrm{H}^{\prime}\right)$ and Pielou (J) diversity indexes (Magurran 2011). To characterize the horizontal structure, the phytosociological parameters commonly used were estimated, as follows: relative density ( $\mathrm{Rd})$, relative dominance (Ro), relative frequency (Rf), coverage index (CV) and importance value (IV), widely discussed and exemplified in Felfili et al. (2011). Vertical structure was analyzed considering lower, middle and upper strata. These limits were defined based on the total average height $(\mathrm{Ht})$ of the trees and on the standard deviation of the height $\left({ }^{\mathrm{S}} \mathrm{Ht}\right)$, according to the criteria of Souza (1999): lower stratum, includes trees with total height less than the average height least one unit of the standard deviation of the total height; middle stratum, the trees with average height equal or least one unit of the standard deviation up to those with average height plus one unit of the standard deviation; upper stratum, the trees with average height equal or plus one unit of the standard deviation. The diametric structure of the species that had the highest importance values was obtained considering the number and range of classes, as shown and described by Felfili \& Rezende (2003). For each species, the Meyer model (Paula et al. 2004) was adjusted to obtain the estimated frequency per diameter class and allow for the application of the balanced forest concept. Diameter distribution of the community was calculated with exponential fit by the Meyer equation and their statistical coefficients determined by regression (determination coefficient $\mathrm{R}^{2}$ ).

\section{Results}

The sample included 749 individuals of 210 tree species from 128 genera and 51 botanical families (Table 1). Among the 


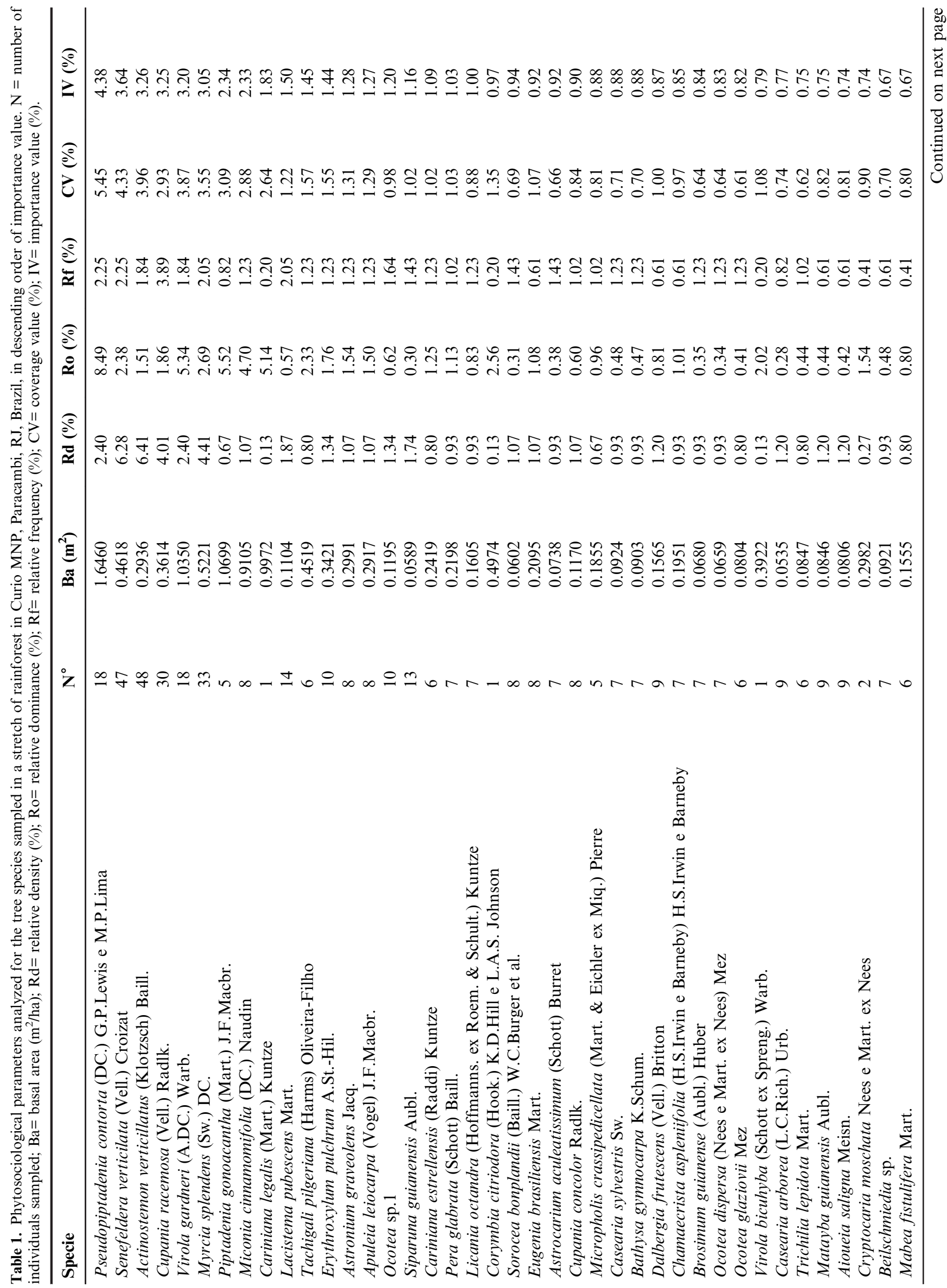




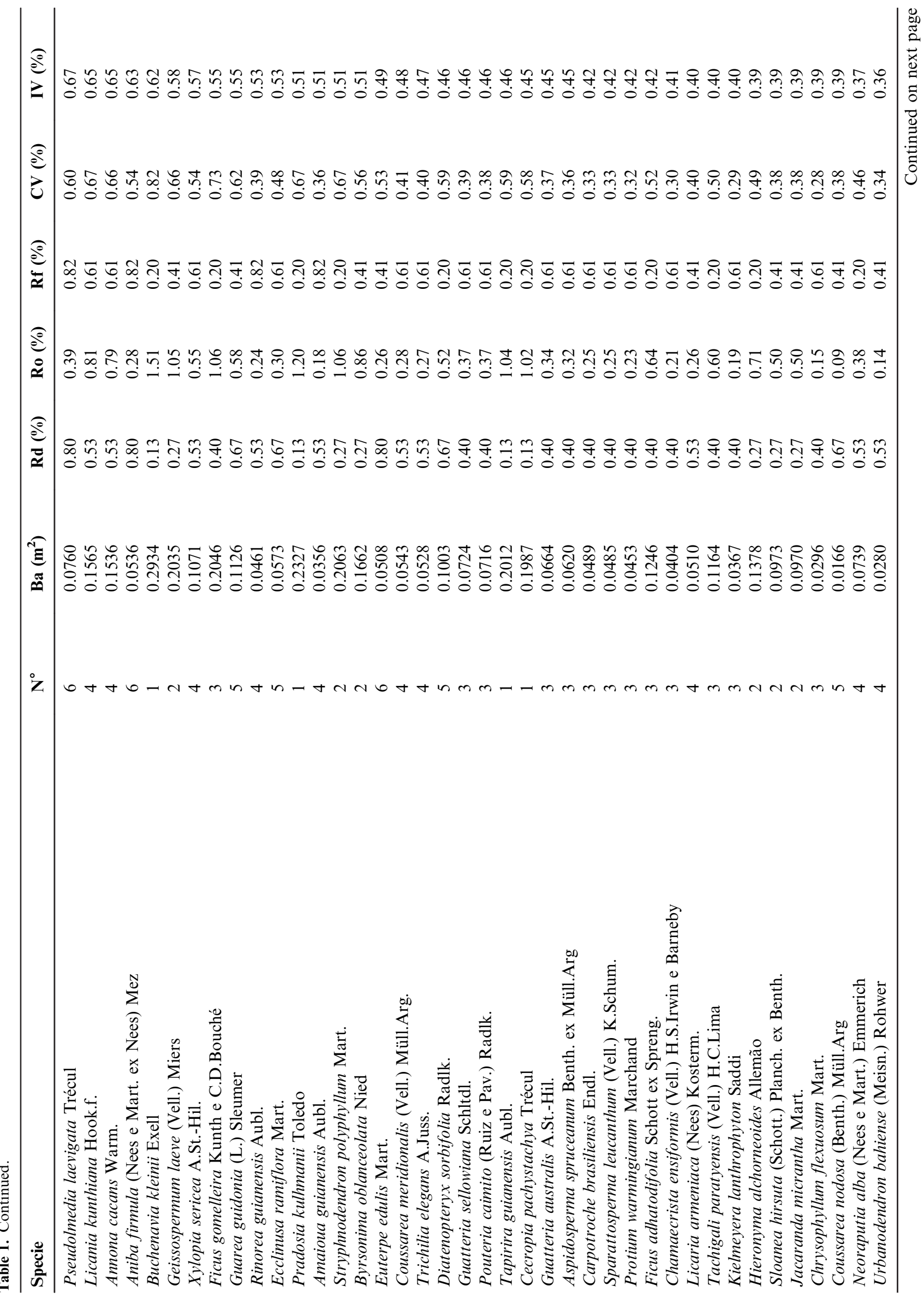




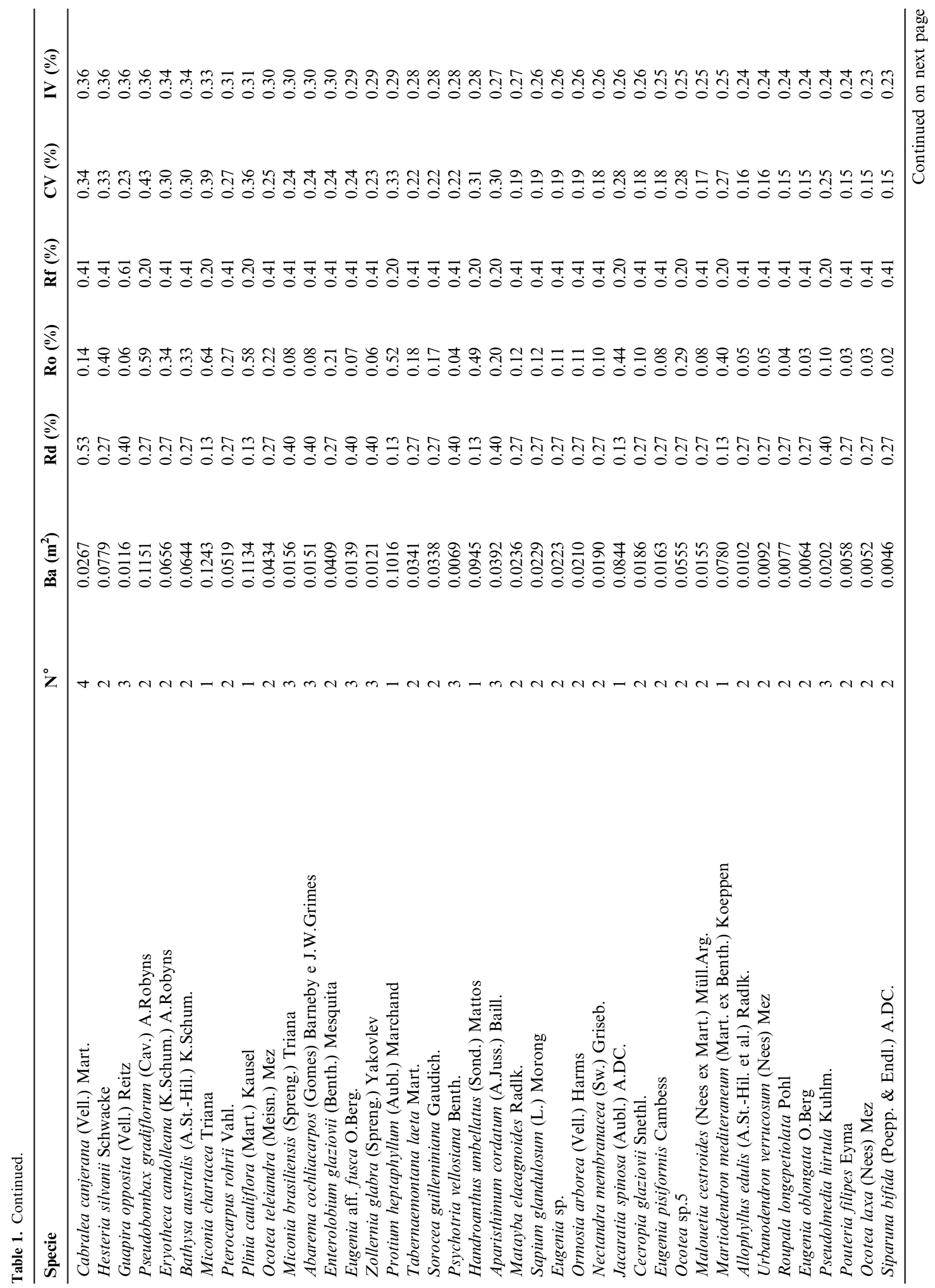




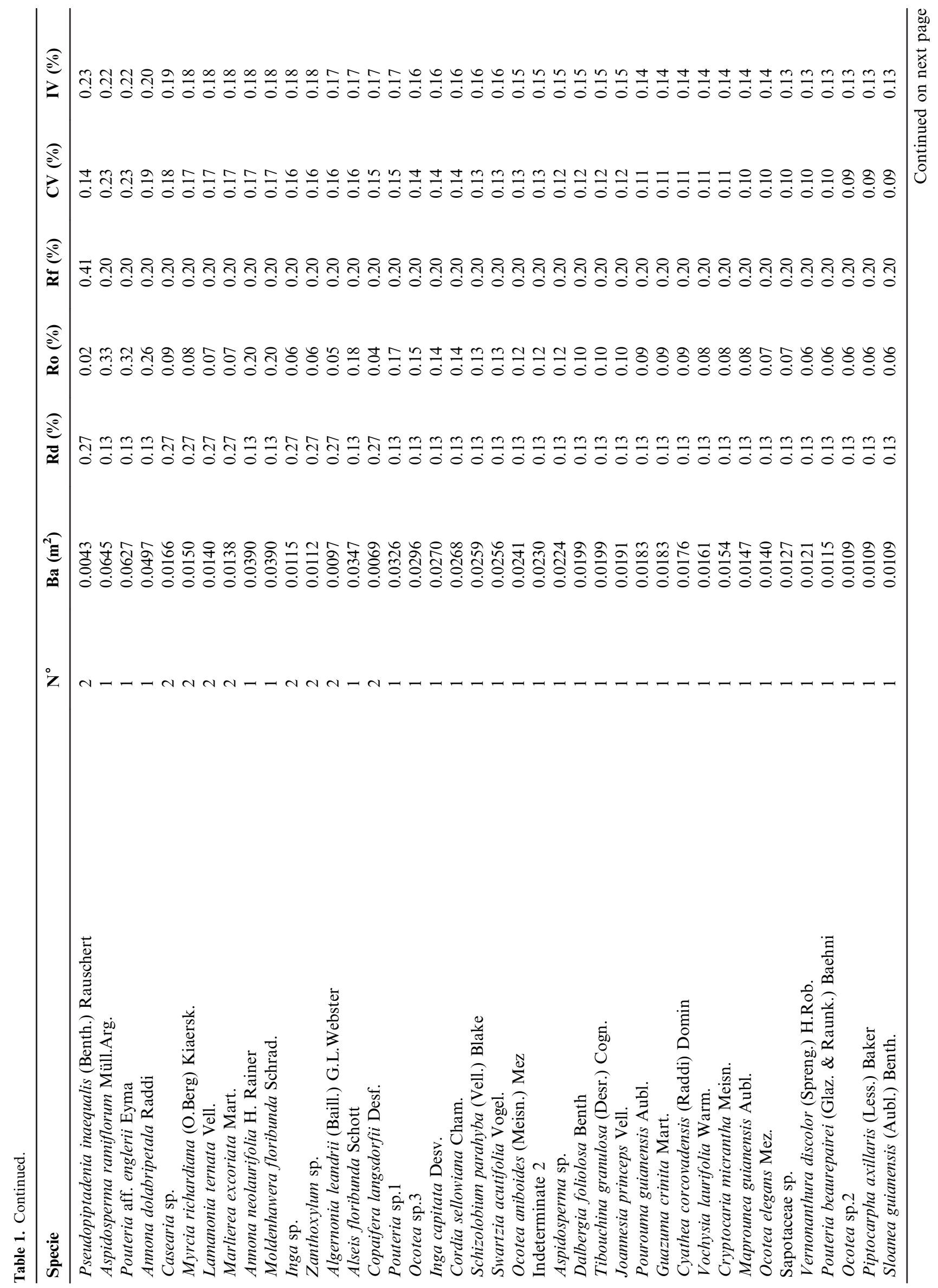




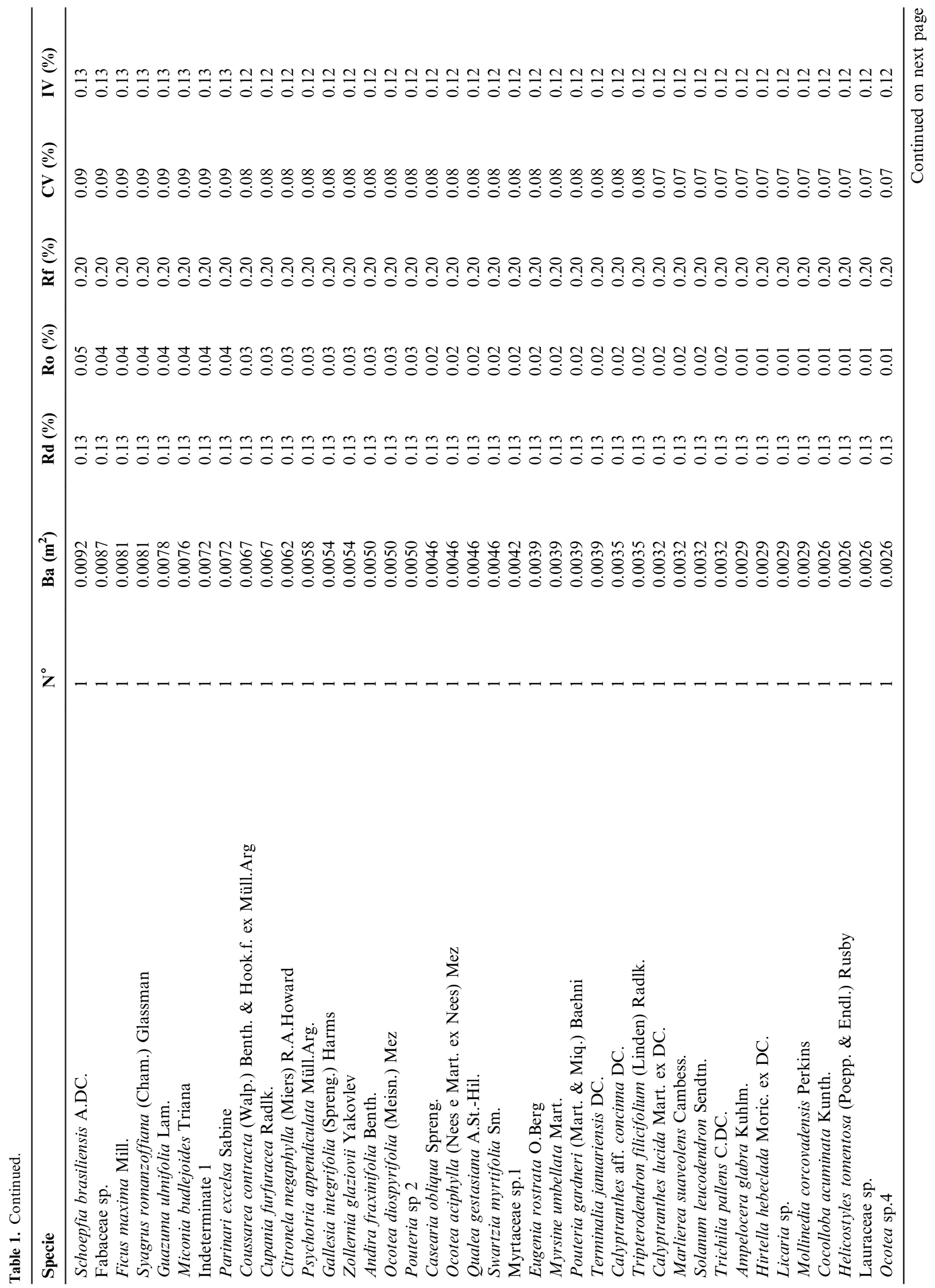




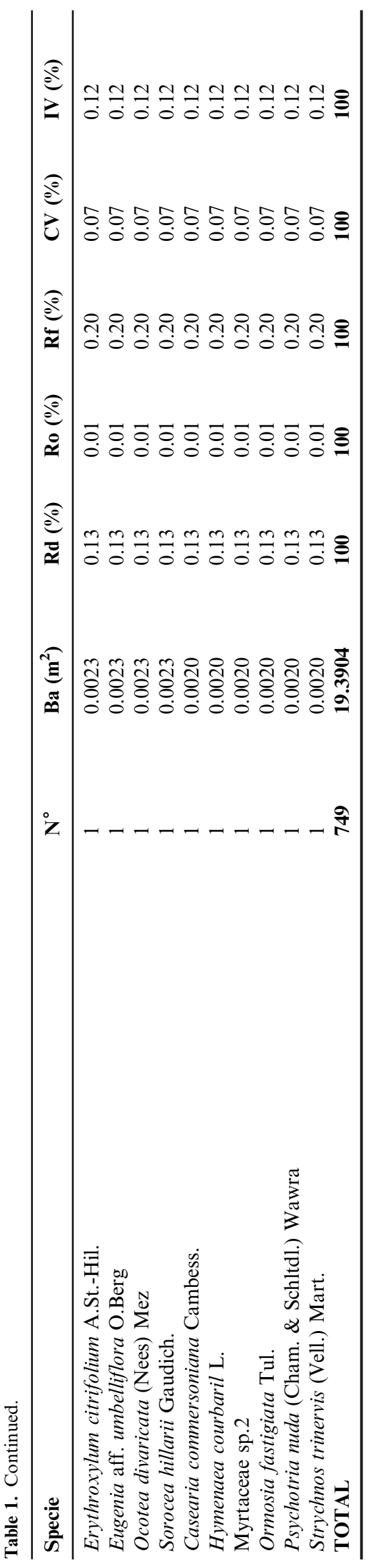

surveyed species, 13 were identified only to the genus level, five at family level and two species remained unidentified. Of the species found, Apuleia leiocarpa, Cariniana legalis, Cupania concolor, Cupania furfuracea, Euterpe edulis, Pradosia kulhmanii, Urbanodendron bahiense and Virola bicuhyba are listed as threatened in Brazilian flora in the endangered or vunerable categories (CNCFLORA 2014). According to the Chao 1 and Jackknife 1 richness estimators, the number of expected species for the community is 323 and 325 , respectively. Thus, the observed richness $(n=210)$ corresponds to $65.7 \%$ of the total estimated richness for the community. The floristic diversity index of Shannon-Weaver $\left(\mathrm{H}^{\prime}\right)$ was 4.7 , and the evenness index (J) was 0.88 . The species accumulation curve showed a smooth curvature (Figure 2), but did not reach the asymptotic value.

A total of 15 dead standing trees were found. The estimated total basal area was $48.48 \mathrm{~m}^{2} /$ hectare (ha) (Table 1). Pseudopiptadenia contorta had the highest importance value (IV), mainly due to its high value of dominance. Senefeldera verticilata, even with low values of relative dominance, had the second highest density value for the community, being second in IV. The species with the third highest IV was Actinostemon verticilatus, which despite having the highest density, showed reduced values of frequency and dominance, due to its clustered pattern of occurrence and small individual size. Cupania racemosa, which ranked fourth in IV, was the most frequent species in the sample and the fourth in density, evenly distributed throughout the study area. Virola gardnerii, the fifth species in IV, had lower density and frequency values, however it held this position due to the large size of its individuals, which generated high levels of dominance $\left(3^{\text {rd }}\right.$ position). The sixth highest IV was held by Myrcia splendens, the third in density, being represented only by individuals of small and medium size. These first six species accounted for $20.77 \%$ of the importance value and $24.1 \%$ of the coverage value $(\mathrm{CV})$, highlighting the importance of these taxa in the forest structure of the Curio MNP. Piptadenia gonoacantha and Miconia cinnamomifolia $\left(7^{\text {th }}\right.$ and $8^{\text {th }}$ IV), which were represented by few individuals, showed high importance values however due to the large size of their individuals. The ninth ranked IV species was Cariniana legalis, which despite being represented by only one individual, had the fourth highest dominance value of the community due to its large diameter $(112 \mathrm{~cm})$.

The individual distribution by diameter class $\left(\mathrm{R}^{2}\right)$ was 0.875 (Figure 3), with an exponential distribution in the form of an "inverted- J" and higher frequency of individuals in the smaller classes. The diameter distribution of the six species of highest importance value (IV) revealed that the majority showed a balanced pattern of distribution. Pseudopiptadenia contorta $\left(\mathrm{R}^{2}=0.6\right)$ and Cupania racemosa $\left(\mathrm{R}^{2}=0.57\right)$ were exceptions, showing a distinct pattern with interruptions between the classes.

The lower stratum included individuals up to 5.1 meters high, the middle, individuals from 5.1 to 15.6 meters, and the higher, with individuals taller than 15.6 meters. The middle stratum was the most abundant in number of individuals $(73.5 \%)$ and species (179). This layer assembles the understory species of medium height and those in the growth phase to the canopy, with greater richness and density. The most common species of the lower stratum were Senefeldera verticilata, Actinostemon verticilatus, Cupania racemosa and Siparuna guianensis. In the upper stratum, Virola gardnerii, Pseudopiptadenia contorta 


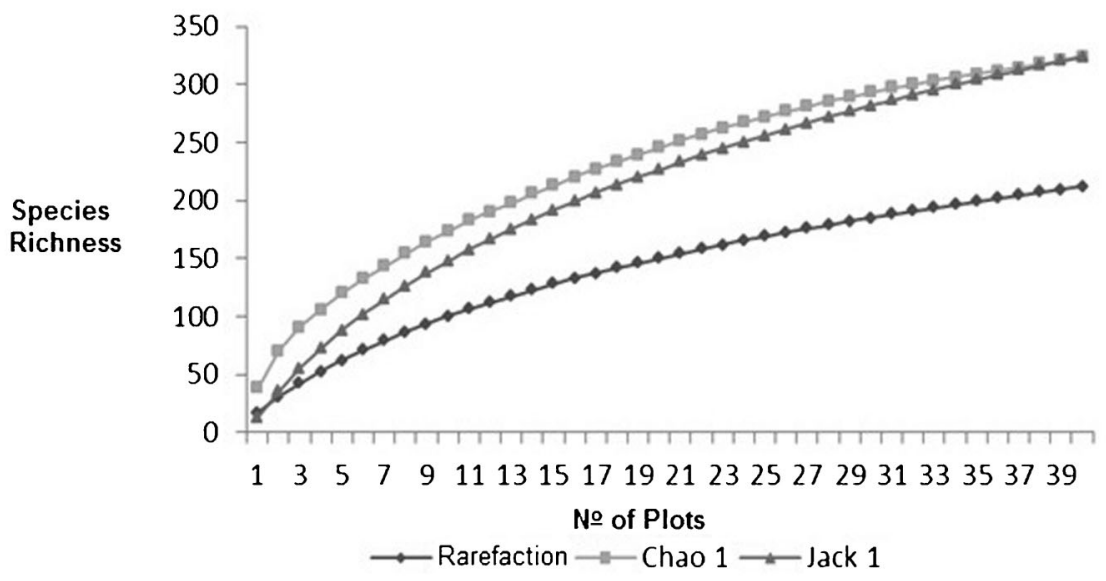

Figure 2. Species accumulation curve and Chao 1 and Jackknife 1 richness estimators for the rainforest in the Curio MNP, Paracambi, RJ, Brazil.

and Myrcia splendens were the most abundant. In addition, many emergent trees above 30 meters high were recorded, such as Pseudopiptadenia contorta, Martiodendron mediterraneum, Apuleia leiocarpa, Cariniana legalis, Miconia cinnamomifolia and Virola gardnerii.

Main parameters used for comparing species richness, diversity and structure with other Atlantic Forest areas studied in the State of Rio de Janeiro are presented in Table 2.

\section{Discussion}

The diversity index registered in the survey was high when compared to values found in other studied areas of Atlantic Rain Forest in Rio de Janeiro. Martins (1991) asserted that, in general, the diversity values obtained for the Atlantic Forest vary from 3.61 to 4.07. For Rio de Janeiro State, Kurtz \& Araújo (2000) suggested a variation from 1.69 to 4.4, depending on the study area. Comparisons should be made with caution, because when considering species equitability in the diversity calculation, these scores may end up assigning lower values for areas with high abundance of some species, which commonly occurs in Atlantic Forest fragments. However, the index of species equitability $(\mathrm{J})$ in the study area $(0.88)$ indicated that the individuals are uniformly distributed among the species. Although higher richness was registered to the Atlantic Forest as a whole, with the highest number recorded by Thomaz \& Monteiro (1997) and Saiter et al (2011) to the state of Espirito Santo, among the studies conducted for this vegetation in the state of Rio de Janeiro, including equal or larger sample areas, the Curio MNP was the one with the greater species richness. The lack of stabilization of the species accumulation curve is, in fact, a pattern to be expected for tropical forests (Schilling \& Batista 2008, Schilling et al. 2012), as well as the high number of species, which also reaffirm the richness and importance for conservation of this forest area. Similarly, the index of species estimation for the study area and the occurrence of threatened species of the national flora also show the importance of the Curio MNP for the maintenance of genetic resources and protection of their habitats. By the other side, this high richness in species may be due to the high altitudinal gradient of the sampled area. The impracticality of identifying some studied species $(10 \%$ of total) reveals that there is still a lack of knowledge of some Atlantic Forest representatives.
Among the studied tree communities in the State, a greater value for basal area than that found in this survey was only found by Kurtz \& Araújo (2000) in the Estação Ecológica Paraiso $\left(57.28 \mathrm{~m}^{2} / \mathrm{ha}\right)$, mainly due to the presence of large remaining individuals. Although broader inclusion criteria may lead to an increase in this variable (Nettesheim et al., 2010), these two studies with the highest values used the same criteria, not as restrictive as other studies in Rio de Janeiro. The total density was 1872 individuals/ha, a relatively high value when compared to that found in other studies in the State of Rio de Janeiro, but lower than those found by Gandra et al. (2011) in PRNP Porangaba (1886 ind/ha) and by Kurtz et al. (2009) on a sandbank of Buzios (2386 ind/ha). Reduced basal area and density may reflect anthropogenic disturbances such as the presence of selective wood extraction (Silva \& Nascimento 2001) or natural factors such as drought and land slope (Guedes-Bruni et al. 2006). Indeed, Borém \& Oliveira-Filho (2002), studying an amended topo-sequence, obtained increasing values of these variables with the reduction of the disturbance gradient. These variables have been shown to be effective indicators of the degree of preservation of an area (Moreno et al. 2003), as long as they are carefully analyzed. In the study area, anthropogenic disturbance is the result of the proximity of the urban area, old abandoned plantations and on-going plant extraction.

Regarding the species with the highest importance values (IV), Borém \& Oliveira -Filho (2002) also found Pseudopiptadenia contorta to be one of the most important in the upper third of a topo-sequence in Silva Jardim, RJ, and attributed this position to the species' high basal area. GuedesBruni et al. (2006) found Senefeldera vertcilata to be the most important species (IV) in three fragments analyzed and explained its position due to its high density values, as was also detected in this study. This was due to the clustered pattern and small size of the individuals. Moreno et al. (2003) also found high levels of coverage and importance for Actinostemon verticilatus at two different altitudes, reflecting its high density in both. Similarly to observations in the present study, a high number of species represented by few individuals (1-2) is a typical factor of forest communities, especially in Brazilian rainforests (Martins 1991, Kurtz \& Araújo 2000, Silva \& Nascimento 2001, Borém \& Oliveira-Filho 2002, Moreno et al. 2003, Carvalho et al. 2007). In general, the occupation strategy 
Atlantic Forest in Rio de Janeiro

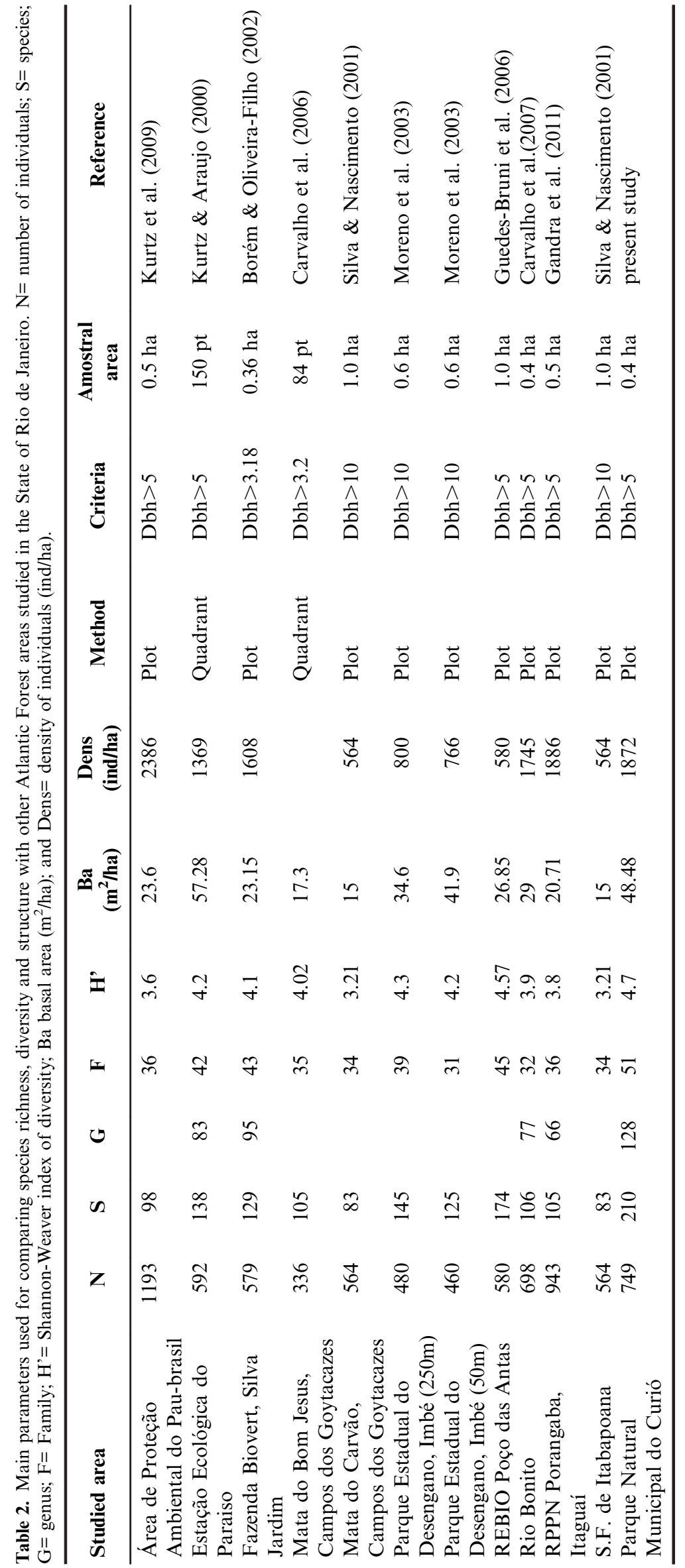



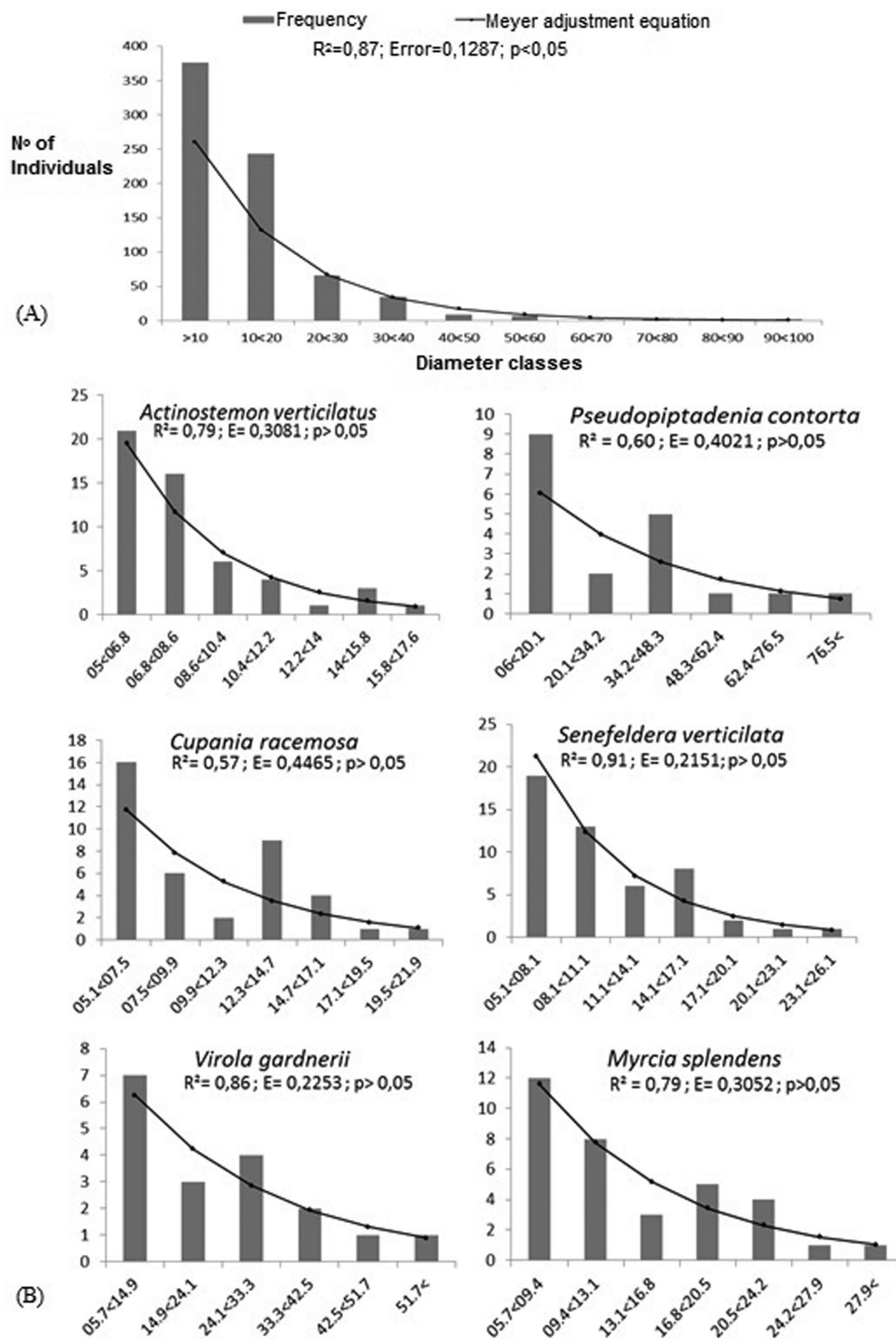

Figure 3. Diameter distribution of the community and of the six tree species with the highest dominance values in a fragment of the rainforest in Curio MNP, Paracambi, RJ, with exponential fit by the Meyer equation and their statistical coefficients. 
of most species is many individuals with reduced size, while a minority has a few individuals of large size (Borém \& OliveiraFilho 2002, Guedes-Bruni et al. 2006). Species with large individuals in the study area, such as Piptadenia gonoacantha and Miconia cinnamomifolia, were cited by Borém \& OliveiraFilho (2002) as ecologically dominant, namely, species that occupy significant positions in IV, albeit at low density. Both are considered pioneers species and indicators of disturbance (Araújo et al. 2006). As these species are represented by a few and large individuals, it is likely declining in the community, indicating that succession is progressing to more advanced stages. In the study area, the only individual of Cariniana legalis (9th in IV) is probably a relic from a primary forest, suggesting maturity in some patches of this forest. Dan et al. (2010) also found species of the same genus with low density in a municipality of northwestern Rio de Janeiro State and, pointing out its abundance in the past, attributed the finding to exploitation of this highly valuable timber species. For many species, however, the low density can also be indicative of very peculiar spatial distribution. The low frequency of $C$. legalis in the area may result from its exploitation or also be caused by a small sample, what suggests the need for further investigations.

The number of dead standing trees $(15 ; 1.96 \%)$ can be considered low when compared to other forests from Rio de Janeiro State. Moreno et al. (2003) mentioned a mortality rate of $1.5 \%$ for a well preserved forest, while Carvalho et al. (2007) found $10.1 \%$ in an area affected by human disturbance. Silva \& Nascimento (2001) also found a $9.76 \%$ mortality rate in a tabuleiro forest and related this to problems caused by fragmentation and the edge effect. The reduced mortality found in the Curio MNP can be another factor that reinforces the maturity and good level of preservation of the studied fragment.

The individual distribution by diameter class $\left(\mathrm{R}^{2}=0.875\right)$ followed the typical pattern pointed out by Soares et al. (2007), which may indicate the capacity for self-regeneration and replacement of individuals on a short time-scale (Felfili 1997). According to Parrota (1993), the occurrence of a greater number of individuals in the lower- diameter classes is a pattern expected for secondary forests, favoring succession and buffering disturbances. The evaluation of the diameter distribution at the community level has been shown to be an important tool for understanding vertical structure in forests. On the other hand, it may be insufficient to assess the condition of the tree component, and therefore analyses at the population level are needed (Martins 1991, Felfili 1997, Paula et al. 2004, Carvalho \& Nascimento 2009). Kurtz \& Araújo (2000) postulated that equilibrated populations have nearly balanced diameter distributions, tending to produce an inverted-J curve, which is typical of species with abundant regeneration and a stable population structure. Carvalho \& Nascimento (2009), when studying the diameter structure of the principal tree populations in a forest remnant in Silva Jardim, RJ, also found balanced patterns for most species, indicating temporal stability in floristic composition and the absence of problems in the regeneration of these populations. In the present study, the large number of individuals of Pseudopiptadenia contorta and Cupania racemosa in the smaller classes suggests their persistence in the forest fragment.

In the Curio MNP, the middle stratum includes understory species of medium height and canopy species in the growth phase, thus showing greater richness and density, as found by
Kurtz \& Araujo (2000) at the Estação Ecológica do Paraíso, where $65.2 \%$ of the richness and $48 \%$ of the individuals were in the middle strata. Dan et al. (2010) also found a greater number of species in the middle of three strata when studying the structure of a tree community in the Santo Domingo River basin of São José de Ubá, RJ. Although using different methodology, Guilherme et al. (2004) detected three well-defined strata for an Atlantic forest area preserved in São Paulo and likewise had greater richness in the middle stratum, although the greater density was found in the lower stratum. By the other side, in the present study the upper stratum showed the highest coverage values, with $55.9 \%$ of the total basal area found, which reflects the large size of the species. Puig (2008) suggested high structural heterogeneity in tropical moist forests, both in their vertical organization and in their horizontal arrangement. It should be emphasized, however, that the vertical structure of tropical forests is still little studied, especially because of the difficulty in precise measurement of this variable in native forests and in its analysis (Guilherme et al. 2004; Machado \& Figueiredo-Filho, 2006). The most frequent species in the lower stratum (Senefeldera verticillata, Actinostemon verticilatus, Cupania racemosa and Siparuna guianensis) are classified as initial secondary or pioneer species, with low shade tolerance and of medium size (Silva et al. 2003, Carvalho et al. 2007). Carvalho et al. (2007), refer to the same species as typical of the understory in secondary forests, highlighting disturbed areas in the Curio MNP. In the upper stratum, Virola gardnerii is mentioned by Carvalho et al. (2007) as a late canopy species, while Pseudopiptadenia contorta is indicated as a long-lived pioneer (Carvalho et al. 2007), related to an intermediate stage of regeneration (Gandolfi et al. 1995). Emergent species (Pseudopiptadenia contorta, Martiodendron mediterraneum, Apuleia leiocarpa, Cariniana legalis, Miconia cinnamomifolia and Virola gardnerii) represent the oldest individuals in the community, being indicative of maturity or an advanced stage of forest succession.

The high diversity and species richness registered, despite the small sample area, is a strong indication of the good condition of the vegetation of the Curio MNP. The high diversity index $\left(\mathrm{H}^{\prime}\right)$ is probably associated with the uniformity found in the distribution of individuals by species. The diameter distributions of the six species with the greatest importance values suggest temporal stability of these populations. The high species richness, high basal area, the presence of large emergent individuals and the low number of dead trees indicate that the forests, even being secondary, can be considered mature, with the prevalence of advanced stages in a successional forest mosaic. Since approximately $30 \%$ of the species are still unknown and the already high number of species found may be due to the high altitudinal gradient of the park area, besides evaluate the richness in different altitudinal quotas further research may reveal other ecologically important species for this vegetation and/or little known. The occurrence of endangered species listed for the Brazilian flora reiterates the importance of the area as a relic fragment of Rio de Janeiro Atlantic Forest still in good environmental condition. Added to this, the lack of floristic knowledge of the region reinforces the need for conservation of this forest to maintain and restore native vegetation, especially in nearby areas. These features taken together point out to the need for constant care and a possible expansion of the boundaries of the park, with the elevation of this conservation area to a state or federal level, which can ensure greater protection of the local biota. 


\section{Acknowledgments}

The authors are grateful to the researchers and other professionals who assisted in reading the manuscript: Alexandre Fernandes Bamberg de Araujo, Daniel Vasquez Figueiredo, José Emanuel Gomes de Araújo, Daniel Costa Carvalho and Felipe Cito Nattesheim. In addition, they thank Tom Adnet for the map, Rachel Arruda for preparation of the herbarium samples, and the taxonomists Genise Vieira Freire, Marcelo da Costa Souza and Alexandre Quinet for their assistance in identifying the families Sapindaceae, Myrtaceae and Lauraceae, respectively. Thanks are also extended to FAETEC, to the municipal office and Secretaria de Meio Ambiente e Desenvolvimento Sustentável of Paracambi City for their accompaniment and assistance.

\section{References}

APG. 2009. An update of the Angiosperm Phylogeny Group classification for the orders and families of flowering plants: APG III. Bot. J. Linn. Soc. 161: 105-121.

ARAÚJO, F.S., MARTINS, S.V., MEIRA-NETO, J.A.A., LANI, J.L. \& PIRES, I.E. 2006. Estrutura da vegetação arbustivo-arbórea colonizadora de uma área degradada por mineração de caulim, Brás Pires, MG. Rev. árvore 30: 107-116.

BERGALHO, H.G. 2009. (Coord.). Estratégias e ações para a conservação da biodiversidade no Estado do Rio de Janeiro Instituto Biomas, Rio de Janeiro. 344p.

BORÉM, R.A.T. \& OLIVEIRA-FILHO, A.T. 2002. Fitossociologia do estrato arbóreo em uma toposseqüência alterada de Mata Atlântica, no Município de Silva Jardim - RJ, Brasil. Rev. árvore 26: 727-742.

CARVALHO, F.A. \& NASCIMENTO, M.T. 2009. Estrutura diamétrica da comunidade e das principais populações arbóreas de um remanescente de Floresta Atlântica submontana (Silva Jardim, RJ, Brasil). Rev. árvore 33: 327-337.

CARVALHO, F.A., NASCIMENTO, M.T. \& BRAGA, J.M.A. 2007. Estrutura e composição florística do estrato arbóreo de um remanescente de Mata Atlântica Sub-Montana no município de Rio Bonito, RJ, Brasil (Mata Rio Vermelho). Rev. árvore 31: 717730.

CARVALHO, F.A., BRAGA, J.M.A., GOMES, J.M.L., SOUZA, J.S. \& NASCIMENTO, M.T. \& 2006. Comunidade arbórea de uma floresta de baixada aluvial no município de Campos dos Goytacazes, RJ. Cerne 12(2): 157-166.

CNCFLORA - Centro Nacional de Conservação da Flora. http:// cncflora.jbrj.gov.br/portal/pt-br/redlisting (Last access on 21 July 2014).

DAN, M.L., BRAGA, J.M.A. \& NASCIMENTO, M.T. 2010. Estrutura da comunidade arbórea de fragmentos Estrutura da comunidade arbórea de fragmentos de floresta estacional semidecidual na bacia hidrográfica do rio São Domingos, Rio de Janeiro, Brasil. Rodriguésia 61: 749-766.

FELFILI, J.M. 1997. Diameter and height distributions of a gallery forest community and some of its main species in central Brazil over a six-year period (1985-1991). Rev. Bras. Bot. 20: 155-162.

FELFILI, J.M. \& REZENDE, R.P. 2003. Conceitos e métodos em fitossociologia. Departamento de Engenharia Florestal, Universidade de Brasília, Brasília. 64p.

FELFILI, J.M., EISENLOHR, P.V., MELO, M.M.R.F., ANDRADE, L.A. \& MEIRA NETO, J.A.A., 2011. Fitossociologia no Brasil: métodos e estudos de casos: Volume 1. Universidade Federal de Viçosa, Viçosa. 556p.

FERREIRA, D.F. 2009. Estatística básica. Universidade Federal de Lavras, Lavras. 664p.

FONSECA, V.S. \& SÁ, C.F.C. 1997. Situación de los estúdios etnobotánicos en ecosistemas costeros de Brasil. In Uso y Manejo de Recursos Vegetales. Memorias del II Simpósio Ecuatoriano de Etnobotánica y Botánica Economica (M. Rios \& H. B. P. Edersen, eds.). Quito p.5781.

FRAGA, M.E., BRAZ, D.M., ROCHA, J.F., PEREIRA, M.G. \& FIGUEIREDO, D.V. 2012. Interação microrganismo, solo e flora como condutores de biodiversidade na Mata Atlântica. Acta bot. bras. 26: 857-865.

GANDOLFI, S., LEITÃO-FILHO, H.F. \& BEZERRA, C.L.F. 1995. Levantamento florístico e caráter sucessional das espécies arbustivo-arbóreas de uma floresta mesófila semidecídua no município de Guarulhos, SP. Rev. Bras. Bot. 55: 753-767.

GANDRA, M.F., NUNES-FREITAS, A.F. \& SCHÜTTE, M.S. 2011. Composição Florística do estrato arbóreo em um trecho de Floresta Atlântica na RPPN Porangaba, no município de Itaguaí, Rio de Janeiro. Floresta Ambient. 18: 87-97.

GUEDES-BRUNI, R.R., PESSOA, S.V.A. \& KURTZ, B.C. 1997. Florística e estrutura do componente arbustivo-arbóreo de um trecho preservado de floresta montana na Reserva Ecológica de Macaé de Cima. In Serra de Macaé de Cima: Diversidade florística e conservação em Mata Atlântica Lima, H.C. Guedes-Bruni, R.R. eds.) Jardim Botânico do Rio de Janeiro Rio de Janeiro, p.127-145.

GUEDES-BRUNI, R.R., MORIM, M.P., LIMA, H.C. \& SYLVESTRE, L.S. 2002. Inventário florístico. In Manual metodológico para estudos botânicos na Mata Atlântica Sylvestre, L.S.Rosa, M.M.T. orgs.). Universidade Federal Rural do Rio de Janeiro, Seropédica, p.24-50.

GUEDES-BRUNI, R.R., NETO, S.J.S., MORIM, M.P. \& MANTOVANI, W. 2006. Composição florística e estrutura de dossel em trecho de floresta ombrófila densa atlântica sobre morrote mamelonar na reserva biológica de Poço das Antas, Silva Jardim, Rio de Janeiro. Rodriguésia 57: 429-442.

GUILHERME, F.A.G., MORELLATO, L.P.C. \& ASSIS, M.A. 2004. Horizontal and vertical tree community structure in a lowland Atlantic Rain Forest, Southeastern Brazil. Rev. Bras. Bot. 27(4): 725-737.

IBGE. 2012. Manual técnico da vegetação brasileira. Manuais técnicos em geociências 1: 1-275.

IPNI - International Plant Name Index. http://www.inpn.org/ (Last access on 13 December 2013).

KURTZ, B.C. \& ARAÚJO, D.S. 2000. Composição florística e estrutura do componente arbóreo de um trecho de Mata Atlântica na Estação Ecológica Estadual do Paraíso, Cachoeiras de Macacu, Rio de Janeiro, Brasil. Rodriguésia 51: 69-112.

KURTZ, B.C., SÁ, C.F.C. \& SILVA, D.O. 2009. Fitossociologia do componente arbustivoarbóreo de florestas semidecíduas costeiras da região de emerenças, Área de Proteção Ambiental do Pau Brasil, Armação dos Búzios, Rio de Janeiro, Brasil. Rodriguésia. 60: 129146.

LEITÃO-FILHO, H.F., PAGANO, S.N., CESAR, O., TIMONI, J.L. \& RUEDA, J.J. 1993. Ecologia da Mata Atlântica em Cubatão (SP). Universidade Estadual de Campinas, Campinas. 184p.

LISTA DE ESPÉCIES DA FLORA DO BRASIL. 2014 Jardim Botânico do Rio de Janeiro. http://floradobrasil.jbrj.gov.br (Last access on 24 February 2014).

MACHADO, S.A. \& FIGUEIREDO-FILHO, A. 2006. Dendrometria. $2^{\mathrm{a}}$ Edição. Universidade Estadual do Centro-Oeste, Guarapuava $316 \mathrm{p}$.

MAGURRAN, A.E. 2011. Medindo a diversidade biológica / Anne E. Magurran, 1955; translation by Dana Mioana Vianna. Universidade Federal do Paraná, Curitiba. 261p.

MARTINS, F.R. 1991. Estrutura de uma Floresta Mesófila. Universidade Estadual de Campinas, Campinas. 91p.

MORENO, M.R., NASCIMENTO, M.T. \& KURTZ, C.B. 2003. Estrutura e composição florística do estrato arbóreo em duas zonas altitudinais na mata atlântica de encosta da região do Imbé, RJ Acta bot. bras. 17: 371-386.

MUELLER-DOMBOIS, D. \& ELLEMBERG, H. 1974. Aims and methods of vegetation ecology. John Wiley \& Sons, Nova York. $547 \mathrm{p}$. 
MYERS, N., MITTERMEIER, R.A., MITTERMEIER, C.G., FONSECA, G.A.B. \& KENT, J. 2000. Biodiversity hotspots for conservation priorities. Nature 403: 853-858.

NETTESHEIM, F.C., CARVALHO, D.C., FONSECA, C.C., NUNES, R.S., CAVALCANTI, D.M., GABRIEL, M.M. \& MENEZES, L.F. 2010. Estrutura e florística do estrato arbóreo no cerrado sensu stricto de Buritis, Minas Gerais, Brasil. Rodriguésia 61: 731-747.

OLIVEIRA-FILHO, A.T. \& FONTES, M.A. 2000. Patterns of floristic differentiation among Atlantic Forest in Southeastern Brazil and the influence of Climate. Biotropica 32: 793-810.

PARROTA, J.A. 1993. Secondary forest regeneration on degraded tropical lands: the role of plantations as faster ecosystems. In Restoration of tropical forest ecosystems (H. Lieth \&, M. Lohmann, eds.). Kluwer Academic Publishers, Dordrecht, p.63-73.

PAUlA, A., SILVA, A.F., DE MARCO JUNIOR, P., SANTOS, F.A.M \& SOUZA, A.L. 2004. Sucessão ecológica da vegetação arbórea em uma floresta estacional semidecidual, Viçosa, MG, Brasil. Acta bot. bras. 18: 407-423.

PEIXOTO, A. 1991. Vegetação da costa atlântica. In Floresta Atlântica Monteiro, S. \& Kaz, L., coords.). Alumbramento, Rio de Janeiro, p.33-42.

PUIG, H. 2008. Floresta Tropical Úmida; tradução de Maria Leonor Frederico Rodrigues Loureiro. Universidade Estadual Paulista, São Paulo; Imprensa Oficial do estado de São Paulo, São Paulo; Institut de Rechérche pour le Développement, França. 496p.

RIBEIRO, M.C., METZGER, J.P., MARTENSEN, A.C., PONZONI, F.J. \& HIROTA, M.M. 2009. The Brazilian Atlantic Forest: How much is left, and how is the remaining forest distributed? Implications for conservation. Biol. conserv. 142: 1144-1156.

SAITER, F.Z., GUILHERME, F.A.G., THOMAZ, L.D. \& WENDT, T. 2011. Tree changes in a mature rainforest with high diversity and endemism on the Brazilian coast. Biodivers. Conserv. 20: 19211949.

SCARANO, F.R. 1998. A comparison of dispersal, germination and establishment of woody plants subjected to distinct flooding regimes in Brazilian flood-prone forest and estuarine vegetation. Oecol. Bras. 4: 177-194.
SCHILLING, A.C.E. \& BATISTA, J.L.F. 2008. Curva de acumulação de espécies e suficiência amostral em florestas tropicais. Rev. Bras. Bot. 31: 179-187.

SCHILling, A.C., BATISTA, J.L.F. \& COUTO, H.Z. 2012. Ausência de estabilização da curva de acumulação de espécies em florestas tropicais. Ciênc. Florest. 22: 101-111.

SCOLFORO, J.R.S. \& MELLO, J.M. 2006. Inventário florestal. UFLA/ FAEPE, Lavras. 561p.

SILVA, A.F. \& LEITÃO-FILHO, H.F. 1982. Composição florística e estrutura deum trecho de mata atlântica de encosta no município de Ubatuba (SP). Rev. Bras. Bot. 5: 43-52.

SILVA, G.C. \& NASCIMENTO, M.T. 2001. Fitossociologia de um remanescente de mata sobre tabuleiros no norte do estado do Rio de Janeiro (Mata do Carvão). Rev. Bras. Bot. 21: 51-62.

SILVA, V.F., VENTURIN, N., OLIVEIRA-FILHO, A.T., MACEDO, R.L.G., CARVALHO, A.C. \& BERG, E.V.D. 2003. Caracterização estrutural de um fragmento de floresta semidecídua no município de Ibituruna, MG. Cerne 91: 92-106.

SOARES, T.S., LEITE, H.G., VALE, A.B., SOARES, C.P.B. \& SILVA, G.F. 2007. Avaliação de um modelo de passo invariante na predição da estrutura de um povoamento de Eucalyptus sp. Rev. árvore 31: 275-283.

SOUZA, A.L. 1999. Estrutura, dinâmica e manejo de florestas tropicais (Notas de aula). Editora UFV, Viçosa. 122p.

STEHMANN, J.R.FORZZA, R.C.SALINO, A.SOBRAL, M.COSTA, D.P.E. \& KAMINO, L.H.Y. (eds.) 2009. Plantas da Floresta Atlântica. Instituto de Pesquisa Jardim Botânico do Rio de Janeiro, Rio de Janeiro 516p.

TABARELLI, M., PINTO, L.P., SILVA, J.M.C., HIROTA, M.M. \& BEDÊ, L.C. 2005. Desafios e oportunidades para a conservação da biodiversidade na Mata Atlântica brasileira. Megadiversidade 1: 132-138.

THOMAZ, L.D. \& MONTEIRO, R. 1997. Atlantic Forest floristic composition for the slopes of the Santa Lúcia Biological Station, municipality of Santa Teresa-ES. Bol. Mus. Biol. Prof. Mello Leitão 7: 3-48.

TROPICOS - Missouri Botanical Garden. http://www.tropicos.org/ (Last accessed on 22 January 2013). 